\title{
Pemantauan Tumbuh Kembang Anak dengan Sindrom Down
}

\author{
Frieda Handayani Kawanto, Soedjatmiko
}

Divisi Tumbuh Kembang, FKUI, Departemen Ilmu Kesehatan Anak RS Dr. Ciptomangunkusumo, Jakarta

\begin{abstract}
Sindrom Down (SD) adalah kelainan genetik yang paling sering ditemukan dan berhubungan dengan retardasi mental. Kelainan yang terjadi disebabkan oleh adanya kelebihan materi genetik kromosom 21 . Karakteristik fisis anak dengan SD cukup jelas sehingga para tenaga kesehatan yang mengadakan kontak awal dengan neonatus, termasuk dokter ahli kebidanan dan kandungan, perawat kamar bersalin, dan dokter umum, dapat mengenali kelainan ini dengan relatif mudah. Anak dengan SD memiliki berbagai masalah kesehatan dan tumbuh kembang yang tak jarang cukup kompleks, maka skrining pra dan pasca natal, intervensi dini, dan pemantauan tumbuh kembang yang terus-menerus perlu dilakukan agar anak dengan SD dapat memiliki kualitas hidup yang lebih baik. Tata laksana medis, dukungan keluarga, pendidikan, dan pelatihan khusus dapat meningkatkan kemampuan anak dengan SD secara bermakna dan menjembatani transisi menuju kedewasaan. (Sari Pediatri 2007; 9(3):185-190).
\end{abstract}

Kata kunci: Sindrom down, intervensi diri, tumbuh kembang

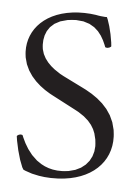

indrom Down (SD) adalah suatu kelainan kongenital multipel akibat kelebihan materi genetik pada kromosom 21 (trisomi). Sindrom Down diambil dari nama seorang dokter berkebangsaan Inggris, John Langdon Down yang pada tahun 1866 menguraikan gambaran sekelompok individu yang tinggal di Earlswood Asylum for Idiots di Surrey, Inggris di tempat dr. Down tersebut bertugas,

\section{Alamat korespondensi}

Dr. Soedjatmiko, Sp.A(K), MSi.

Divisi Tumbuh Kembang Pediatri Sosial. Departemen Ilmu Kesehatan Anak FKUI-RSCM. Jl. Salemba no. 6, Jakarta 10430.

Telepon: 021-3160622. Fax.021-3913982 anak dengan retardasi mental dan memiliki penampakan wajah yang khas dan mirip satu sama lain. Dasar biologis kelainan ini baru dapat diungkapkan tahun 1959 saat Jerome LeJeune menemukan bahwa semua individu dengan gambaran khas tersebut memiliki cetakan ketiga (third copy) kromosom 21 sehingga individu tersebut memiliki 47 kromosom.

Sindrom Down berkaitan dengan retardasi mental, kelainan kongenital terutama jantung, dan disfungsi/ penyakit pada beberapa organ tubuh. ${ }^{3}$ Derajat retardasi mental bervariasi, mulai dari retardasi mental ringan (IQ:50-70) hingga sedang (IQ:35-49), dan kadang (jarang) ditemukan retardasi mental berat (IQ: 2034). ${ }^{4,5}$ Derajat retardasi mental pada anak SD adalah ringan dan sedang. 
Anak dengan SD memiliki berbagai kelainan kongenital dan masalah kesehatan, di antaranya gangguan pendengaran $(75 \%)$, otitis media $(50 \%$ $70 \%)$, kelainan mata (60\%) termasuk katarak (15\%) dan gangguan refraksi berat (50\%), kelainan jantung bawaan (50\%), obstructive sleep apnea (50\%-75\%), penyakit tiroid $(15 \%)$, atresia gastrointestinal (12\%), dislokasi sendi panggul yang didapat (6\%), leukemia dan penyakit Hirschprung $(<1 \%)^{2,3}$

Insidens SD di Amerika Serikat diperkirakan terjadi tiap 600-800 kelahiran hidup, ${ }^{4}$ sedangkan di Indonesia angka yang definitif masih belum diketahui. Meskipun demikian, sebuah penelitian di Universitas Indonesia memperkirakan bahwa 300.000 anak dengan SD lahir per tahunnya.

\section{Diagnosis anak dengan Sindrom Down}

\section{Uji tapis pascanatal}

Sensitivitas petanda uji tapis untuk sindrom Down berkisar antara 61\%-67\%. Pada ibu yang mengandung fetus dengan SD seringkali didapatkan kadar serum maternal alfa-fetoprotein dan unconjugated estriol yang lebih rendah dari normal. Sebaliknya kadar serum maternal beta-human chorionic gonadotropin (betahCG) didapatkan lebih tinggi dari normal. ${ }^{6,8} \mathrm{Uji}$ diagnostik prenatal yang dapat dilakukan adalah pemeriksaan sampel vilus korionik, amniosentesis, dan percutaneus blood sampling, dengan tingkat akurasi 98$99 \%$.

\section{Uji tapis postnatal}

Diagnosis SD pascanatal didasarkan pada gabungan gambaran fisis yang khas dan konfirmasi dengan pemeriksaan kariotipe genetik. Seringkali tanda awal yang dapat ditemui pada neonatus dengan SD adalah hipotoni. Gambaran khas lainnya adalah brakisefal, fisura palpebra yang oblik, jarak antara jari kaki ke-1 dan ke-2 yang agak jauh, jaringan kulit yang longgar di belakang leher, hiperfleksibilitas, low set ears, protrusi lidah, depressed nasal bridge, lipatan epikantus, bercak Brushfield (titik-titik kecil pada pupil yang letaknya tidak beraturan dan berwarna kontras), jari ke-V yang pendek dan melengkung, simian crease, dan didapatinya tanda-tanda penyakit jantung bawaan. ${ }^{2,3,6,8}$ Bila para klinisi mencurigai adanya SD, maka sebaiknya dilakukan pemeriksaan kariotipe atau analisis kromosom untuk penegakan diagnosis definitif. $3,6,8,9$

\section{Masalah kesehatan pada anak dengan Sindrom Down}

Anak dengan SD memiliki berbagai kelainan kongenital yang memerlukan penanganan medis, kelainan itu antara lain,

- Kelainan jantung

Kelainan jantung bawaan ditemukan pada $40 \%-$ $60 \%$ bayi dengan SD, berupa defek kanal atrioventrikular komplit (60\%), defek septum ventrikel $(32 \%)$, tetralogi Fallot $(6 \%)$, defek septum atrium sekundum (1\%), dan isolated mitral cleft (1\%). ${ }^{8,11}$ Anak SD dengan kelainan jantung bawaan berat yang stabil secara klinis dapat memberikan gejala berat setelah usia 8 bulan.

- Gangguan pendengaran

Anak SD seringkali mengalami gangguan pendengaran, baik sensorineural maupun konduktif. emua bayi dengan SD perlu dievaluasi dengan Auditory Brainstem Response Test (ABR) atau dengan transient evoked otoacoustic emission test.

- Masalah penglihatan

Katarak kongenital adalah masalah serius bagi bayi dengan SD, tidak adanya red reflex, terdapatnya nistagmus dan strabismus. ${ }^{9,11}$

\section{Kelainan telinga, hidung, dan tenggorok}

Obstruksi saluran nafas adalah masalah yang berat pada anak dan dewasa dengan SD. Gejalanya meliputi bunyi nafas mendengkur, posisi tidur yang kurang lazim (duduk atau membungkuk sampai kepala menyentuh lutut), kelelahan di siang hari, atau adanya perubahan perilaku. Gejala-gejala tersebut harus dievaluasi dengan baik untuk mencari adanya bukti obstructive sleep apnea. ${ }^{3,8,11}$ Sinusitis, dengan sekret nasal yang purulen, sering ditemui dan memerlukan tata laksana segera. ${ }^{11}$

\section{Penyakit infeksi dan gangguan imunitas}

Pada anak dengan SD yang menderita infeksi sistemik dan respiratorik berulang yang berat perlu dilakukan evaluasi terhadap status imunnya. Kadar IgG total seringkali normal walaupun didapatkan defisiensi sub 
kelas 2 dan 4 atau peningkatan sub kelas 1 dan 3 . Didapatkan korelasi yang nyata antara penurunan IgG sub kelas 4 dengan terjadinya infeksi bakterial. Penurunan imunitas seluler pada anak dengan SD berpengaruh pada kejadian gingivitis dan penyakit periodontal. ${ }^{11}$ Anak SD dengan penyakit jantung dan penyakit saluran nafas kronik sebaiknya mendapat vaksinasi pneumokokus dan influenza. ${ }^{11}$

\section{Masalah instabilitas atlantoaksial (IAA)}

Menggambarkan peningkatan mobilitas servikal 1 dan 2 (sekitar 14\% kasus SD). Sebagian besar kasus IAA asimtomatis, hanya sekitar $10 \%$ yang simtomatis. Gejala yang mungkin timbul adalah nyeri leher, postur kepala yang tidak lazim, tortikolis, perubahan cara berdiri, kehilangan kekuatan tubuh bagian atas, refleks neurologis abnormal, dan terjadi gangguan miksi dan defekasi. ${ }^{8,11}$ Saat ini dianjurkan untuk melakukan uji tapis IAA pada anak SD usia 3-5 tahun. Skrining dilakukan dengan membuat foto servikal lateral dengan posisi netral, fleksi, dan ekstensi. ${ }^{10}$ Evaluasi harus dilakukan berkala pada usia 12 tahun, 18 tahun, dan satu kali pada saat dewasa. ${ }^{11,12}$

\section{Masalah hematologi}

Leukemia yang lebih sering dijumpai pada anak dengan SD berusia kurang dari 3 tahun adalah tipe nonlimfositik (leukemi mielositik akut/LMA). Anak SD biasanya memberikan respons cukup baik dengan terapi standar dan dapat mencapai remisi pada sekitar $80 \%$ kasus. ${ }^{6,10}$ Pada masa neonatus, didapatkan $10 \%$ insidens gangguan mieloproliferatif (reaksi leukemoid) yang pada beberapa kasus dapat berkembang menjadi LMA. Polisitemia juga cukup sering ditemui pada neonatus. Suatu laporan menyatakan $64 \%$ anak dengan SD mengalami polisitemia pada saat neonatus. ${ }^{11}$

\section{Masalah endokrin}

Angka kejadian penyakit tiroid meningkat di antara penderita SD. Hipotiroid, baik kongenital maupun didapat, adalah yang paling sering dijumpai (1620\%). ${ }^{3}$ Tanda dan gejala hipotiroid kadang tidak jelas. Uji tapis penyakit tiroid dianjurkan untuk dilakukan setiap tahun dengan pemeriksaan TSH dan T4. Karena penyakit autoimun banyak ditemui pada anak dengan $\mathrm{SD}$, maka sebaiknya evaluasi hipotiroid dengan pemeriksaan antibodi tiroid juga dilakukan pada anak usia sekolah untuk mencari kemungkinan tiroiditis. ${ }^{11,12}$ Pada beberapa bayi dan anak dengan SD ditemukan kelainan hipertirotropinemia idiopatik dengan TSH yang meningkat dan T4 yang normal. Hal ini dapat merupakan akibat defek neuroregulator TSH yang berada dalam batas normal sampai batas atas, bila dipantau selama 24 jam. Oleh karena itu, pemeriksaan TSH dan T4 dianjurkan setiap 6 bulan dan tidak diterapi kecuali bila didapatkan kadar T4 yang rendah. ${ }^{11}$

\section{Masalah gigi-geligi}

Terdapat beberapa masalah orofasial pada anak SD seperti masalah erupsi gigi (terlambat, urutan erupsi yang tidak biasa), adanya gigi yang tidak tumbuh, baik primer maupun permanen, bentuk gigi yang kecil atau abnormal, fisura pada lidah dan bibir serta gigi yang bertumpuk karena rongga mulut yang kecil dan penyakit periodontal. ${ }^{8,10,11}$ Perlu dilakukan perawatan ortodonti setiap 6 bulan. ${ }^{11}$

\section{Gangguan psikiatri}

Gangguan ini ditandai dengan adanya perubahan perilaku, penurunan intektual, dan kemampuan fungsional. Anak SD dengan retardasi mental sedang atau berat mungkin tidak dapat mengungkapkan pemikiran dan persepsi mereka. Anak yang menderita retardasi mental ringan masih dapat menjawab pertanyaan pemeriksa dengan lebih akurat dan dapat mengungkapkan perasaan, pemikiran, dan persepsi mereka. ${ }^{11}$

\section{Masalah neurologi}

Angka kejadiannya mencapai 5\%-10\%. ${ }^{3}$ Tampak hubungan antara umur dan prevalens kejang pada SD, dengan puncak kejadian kejang pada masa bayi dan berulang pada dekade keempat atau kelima dalam hidupnya. Tampak pula bahwa kejadian kejang menurun selama masa dewasa. Spasme infantil adalah tipe kejang yang paling sering muncul pada bayi dan dapat terkontrol dengan steroid atau antikonvulsan lainnya. ${ }^{3,11}$ Angka kejadian kejang yang meningkat tidak semata-mata akibat perkembangan otak yang abnormal, namun dapat terjadi akibat adanya defek jantung, infeksi, maupun gangguan neurotransmiter. 
Gangguan autistik tampaknya lebih sering dijumpai pada anak dan dewasa dengan SD., ${ }^{3,11}$ Angka kejadian autisme pada populasi umum adalah 15 tiap 10000 populasi, dengan prevalensi SD sekitar 5\%-10\%. ${ }^{3}$

\section{Program Intervensi Dini}

Program intervensi dini adalah program sistematis yang berisi terapi, latihan, dan aktivitas yang dirancang untuk menangani keterlambatan perkembangan dan meminimalkan dampak negatif keterlambatan itu sendiri yang dialami anak dengan SD atau cacat lain. ${ }^{14}$ Program intervernsi dini umumnya terdiri dari terapi bicara dan bahasa, terapi fisis, ${ }^{15}$ dan terapi okupasi. ${ }^{16}$

\section{Pemantauan pertumbuhan dan perkembangan anak dengan SD}

\section{Pemantauan pertumbuhan}

Perawakan pendek merupakan tanda kardinal anak dengan SD. Retardasi pertumbuhan sudah terjadi sejak masa prenatal. Setelah lahir, penurunan kecepatan pertumbuhan paling banyak terjadi saat anak berusia 6 bulan sampai 3 tahun. Beberapa kondisi yang menyebabkan pertumbuhan terlambat adalah penyakit jantung bawaan, defisiensi hormon tiroid, coeliac disease, obstuksi saluran nafas atas, dan defisiensi zat gizi akibat kesulitan makan. ${ }^{17}$ Pubertas muncul lebih awal dan terjadi gangguan percepatan pertumbuhan (growth spurt). ${ }^{7}$ Pada penelitian yang dilakukan oleh Kimura $\mathrm{dkk}^{18}$ anak SD Jepang didapatkan hasil nilai tengah tinggi badan anak SD sebelum pubertas adalah sekitar -2SD lebih rendah dibandingkan anak normal. Percepatan pertumbuhan terjadi 1 tahun lebih awal.

Kurva pertumbuhan yang saat ini dipakai di Indonesia adalah kurva pertumbuhan yang dibuat berdasarkan data anak SD di Amerika Serikat oleh Cronk $\mathrm{dkk}^{19}$ tahun 1988. Parameter pertumbuhan seperti berat badan, tinggi badan, dan lingkar kepala dicantumkan pada kurva pertumbuhan khusus anak SD. ${ }^{8}$ Suatu penelitian yang dilakukan oleh Warner $\mathrm{dkk}^{20}$ menunjukkan bahwa faktor nutrisi dapat berperan dalam menambah tinggi badan anak SD. Beliau menambahkan Harrell's formula, terdiri dari HAP Caps, flaxseed oil, dan N,N-dimethylglycine, ke dalam diet anak SD. Hasilnya didapatkan peninggian tinggi badan pada anak-anak tersebut. Meskipun demikian, American College of Medical Genetics pada tahun 1996 mengeluarkan pernyataan bahwa tidak ditemukan bukti ilmiah manfaat suplementasi vitamin, mineral, asam amino, hormon, maupun kombinasi enzim pada perkembangan mental anak dengan SD. ${ }^{21}$

Pemantauan perkembangan

Evaluasi psikologis secara rutin dilakukan pada anak SD sebagai bagian dari penilaian multidisipliner. Uji psikologis formal biasanya dilakukan saat anak SD berumur 2-3 tahun atau saat anak akan ditempatkan dalam kelas prasekolah. Terdapat empat alasan dilakukannya uji psikologis mengetahui kekuatan dan kelemahan anak dan mendeteksi adanya keterlambatan perkembangan, menentukan intervensi terbaik bagi anak, memantau kemajuan anak dan efektifitas intervensi yang diberikan, dan memberikan gambaran kepada orangtua mengenai kemampuan anak dan saran tentang apa yang harus dilakukan. ${ }^{22}$

Evaluasi psikologis menilai kemampuan kognitif, adaptif, dan perilaku. Kemampuan kognitif mencakup kemampuan verbal, memori, dan motorik-visual yang dinilai dengan melihat kemampuan anak menamai suatu gambar, memilih kata-kata dalam menjawab pertanyaan, mengulang kalimat, dan menyusun balok. Kemampuan adaptif adalah kemampuan anak melakukan pekerjaan sehari-hari. Termasuk dalam kemampuan adaptif adalah kemampuan komunikasi, kemampuan mengurus diri sendiri seperti memakai baju dan menggunakan toilet, dan kemampuan bermain dan berbagi dengan teman seusia mereka. ${ }^{23,24}$

Beberapa instrumen yang dapat dipakai untuk menilai kemampuan kognitif anak dengan SD adalah Bayley mental scale of infant development second edition (BSID-II), Stanford-Binet intelligence scale fourth edition, Wechsler preschool and primary scale of intelligence-revised (WPPSI-R), dan Wechsler intelligence scale for childreniii (WISC-III). ${ }^{24}$ Bayley Mental Scale menilai perkembangan kognitif anak yang mencakup percakapan verbal, memori jangka pendek, visual-motor, pengenalan bentuk, imitasi suara dan gerakan, angka, dan menghitung pada anak berusia 2-30 bulan..$^{23,24}$ Penelitian yang dilakukan oleh Niccols dan Latchman ${ }^{24}$ menyebutkan bahwa BSID-II sensitif untuk menilai perkembangan mental bayi SD pada 2 tahun pertama.

Stanford-Binet digunakan untuk menilai memori jangka pendek, kemampuan verbal, dan kemampuan berhitung pada anak usia 2-18 tahun. WPPSI-R digunakan untuk menilai kemampuan adaptif anak 
usia 3 tahun -7 tahun 3 bulan. Kemampuan yang dinilai adalah kemampuan verbal (misalnya jumlah perbendaharaan kata-kata) dan kemampuan memahami apa yang dilihat (visual reasoning skills). Hasil penilaian dalam bentuk skoring Verbal IQ, Performance IQ, dan Full Scale IQ. ${ }^{24,26}$

Kemampuan verbal anak usia 2-18 tahun dapat diukur dengan The expressive one-word picture vocabulary test-revised (untuk menilai kemampuan bahasa ekspresif) dan The peabody picture vocabulary test (untuk menilai kemampuan bahasa reseptif). ${ }^{24,26}$ Untuk menilai kemampuan adaptif dalam hal komunikasi, sosialisasi, kemampuan motorik, dan kemampuan melakukan pekerjaan sehari-hari, dipakai Vineland adaptive behavior scales (VABS). Uji ini dapat dipakai untuk semua kelompok umur. ${ }^{24,25}$

\section{Kesimpulan}

Anak dengan sindrom down (SD) memiliki kelainan bawaan multipel dan mengalami retardasi mental. Kelainan bawaan menyebabkan gangguan pada kesehatan dan pertumbuhan anak SD. Dibutuhkan pemeriksaan fisik dan pemeriksaan penunjang berkala oleh tenaga medis profesional, untuk memantau dan menjaga kesehatannya. Selain pemeliharaan kesehatan, anak SD perlu diberi latihan dan terapi dini agar mampu melakukan pekerjaan sehari-hari dan dapat beradaptasi dengan lingkungannya. Oleh sebab itu, dibutuhkan bantuan keluarga, teman, dan masyarakat untuk mendukung perkembangan mental anak SD. Perlu kerjasama yang baik dari berbagai pihak demi tercapainya kondisi kesehatan, pertumbuhan, dan perkembangan yang baik pada anak dengan SD.

\section{Daftar Pustaka}

1. Van Cleve SN, Cohen WI. Part 1: Clinical practice guidelines with Down syndrome from birth to 12 years. J Pediatric Health Care 2006; 20:47-54.

2. Committee on Genetics American Academy of Pediatrics. Health supervision for children with Down syndrome. Pediatrics 2001; 107;2:442-9.

3. Cohen WI. Down syndrome. Dalam: Maria BL, Gilliam JE, Darby CP, penyunting. Current management in child neurology. Edisi ke-3. London: BC Decker Inc; 2005. h. 297-303.
4. Leshin L. A brief history. Diunduh dari www. $d s$ health.com. Diakses tanggal 2 April 2007.

5. Sularyo TS, Kadim M. Retardasi mental. Sari Pediatri 2000; 2:170-7.

6. Hall JG. Chromosomal clinical abnormalities. Dalam: Behrman RE, Kliegman RM, Jenson HB, penyunting. Nelson Textbook of Pediatrics. Edisi ke-17. Pennsylvania: Saunders; 2004. h. 384-6.

7. Myrelid A, Gustafsson, Ollars B, Anneren G. Growth charts for Down's syndrome from birth to 18 years of age. Arch Dis Child 2002; 87:97-103.

8. Saenz RB. Primary care of infants and young children with Down Syndrome. Am Fam Phys 1999;59;2. Diunduh dari http://www.aafp.org/afp/990115ap/ 381.html.

9. O'Keefe L. Caring for children with Down syndrome. AAP News 2002; 21:290

10. Anonymous. New recommendations for Down syndrome call for screening of all pregnant women. Diunduh dari http://www.acog.org/from_home/publications/press_releases/ nr01-02-07-1.cfm. Diakses tanggal 4 Maret 2007.

11. Cohen WI. Health care guidelines for individuals with Down syndrome (Down syndrome preventive medical check list). Down syndrome quarterly 1996;1;2. Diunduh dari http://denison.edu/dsq/collaborations/dsq/ health96.html. Diakses tanggal 2 April 2007.

12. Clinical Practice Guideline Development Panel. Report of the recommendations: Down syndrome assessment and intervention for young children (age 0-3 years). Diunduh dari http://www.health.state.ny.us/community/ infants_children/early_intervention/docs/guidelines_ down_syndrome_assessment_and_intervention.pdf. Diakses tanggal 1 April 2007.

13. Winders PC. The goal and opportunity of physical therapy for children with Down syndrome. Down syndrome quarterly. Diunduh dari: http://www.denison.edu/ collaborations/dsq/windersphysicaltherapy. html. Diakses tanggal 13 Maret 2007.

14. Anonymous. Early intervention. Diunduh dari http:// www1.ndss.org/index.php?option=com_content\&task= view orid $=1934$ \&ltemid $=235$. Diakses tanggal 4 Maret 2007.

15. Kumin L. Comprehensive speech and language treatment for infants, toddlers, and children with Down syndrome. Diunduh dari http://www.ds-health.com/ speech.htm. Diakses tanggal 13 Maret 2007.

16. Curry JM. Occupational therapy services for infants and children. Diunduh dari http://www.kennedykrieger.org/ kki_misc.jsp?pid=2138. Diakses tanggal 7 Maret 2007. 
17. Styles ME, Cole TJ, Dennis J, Preece MA. New crosssectional stature, weight, and head circumference references for Down's syndrome in the UK and Republic of Ireland. Arch Dis Child 2002; 87:104-8.

18. Kimura J, Tachibana K, Imaizumi K, Kurosawa K, Kuroki Y. Longitudinal growth and height velocity of Japanese children with Down's syndrome. Acta Paediatr 2003; 92:1039-42.

19. Cronk C, Crocker CA, Pueschel SM, Shea AM, Zackai E, Pickens G, dkk. Growth charts with Down syndrome: 1 month to 18 years of age. Pediatrics 1988 ; 81:102-10.

20. Thiel RJ. Growth effects of the Warner protocol for children with Down syndrome. J Ortho Med 2002; 17:42-8.

21. Leshin L. Nutritional supplements for Down syndrome: A highly questionable approach. Diunduh dari http:// www.altonweb.com/cs/downsyndrome/index.htm?page= autismpd.html. Diakses tanggal 5 April 2007.
22. Pulsifer MB. Cognitive development and the psychological evaluation. Diunduh dari http:// www.kennedykrieger.org/kki_misc.jsp?pid $=2132$. Diakses tanggal 4 April 2007.

23. Biasini FJ, Grupe L, Huffman L, Bray NW. Mental Retardation: A symptom and a syndrome. Diunduh dari http://www.uab.edu./cogdev/mentreta.htm. Diakses tanggal 4 April 2007.

24. Niccols A, Latchman A. Stability of the Bayley Mental Scale of infant development with high risk infants. British J Dev Disabilities 2002; 48:3-13.

25. Sattler JM. Mental retardation. Dalam: Sattler JM. Assessment of children: behavioral and clinical applications. Edisi ke-4. San Diego: Sattler, Jerome M, Publisher; 2002. h. 336-43.

26. Decker BR, Joanne J. Pediatrics: Assessment of specific functions. Dalam: Van Deusen J, Brunt D, penyunting. Assessment in occupational therapy and physical therapy. Edisi ke-4. Philadephia: Saunders; 2002. h. 377-96 